\title{
Peroxidase-Like Properties of Multiple Nano-Metallic Oxides under Various Conditions
}

\author{
Ting Liu, ${ }^{\dagger, a}$ Kunfeng Zhao, ${ }^{\dagger, b}$ Linyu Jin, ${ }^{\dagger, a}$ Jun Zhu, ${ }^{b}$ Yamei Dong, ${ }^{b}$ \\ Yinan Yan, ${ }^{b}$ Ping Wang, ${ }^{,{ }^{, b}}$ and Dannong $\mathrm{He}^{{ }^{*}, a, b}$ \\ ${ }^{a}$ School of Materials Science and Engineering, Shanghai Jiao Tong University, Shanghai 200240, China \\ ${ }^{b}$ National Engineering Research Center for Nanotechnology, Shanghai 200241, China
}

\begin{abstract}
Six types of different nano-metallic oxides were studied as peroxidase-like enzyme. By changing the amounts of nano-metallic oxides, $\mathrm{pH}$ value, the concentration of $\mathrm{H}_{2} \mathrm{O}_{2}$, reaction time, and so on, the peroxidase-like characteristics of all the six nano-metallic oxides were probed, and four of them $\left(\mathrm{Co}_{3} \mathrm{O}_{4}, \mathrm{CrO}_{x}, \mathrm{NiO}, \mathrm{MnO}_{x}\right)$ have the oxidase-like properties in the absence of $\mathrm{H}_{2} \mathrm{O}_{2}$, which is of great importance in the application of degrading phenolic pollutants in waste water.
\end{abstract}

Keywords nano-metallic oxides, peroxidase-like enzyme, $\mathrm{H}_{2} \mathrm{O}_{2}$

\section{Introduction}

Biological enzyme is a type of catalytic function of protein. It can accelerate reaction speed in small amounts and has a high catalytic efficiency, exclusive reaction, mild reactive conditions. However, it is difficult to purify the enzyme; moreover, it is easy to lose its activity and the costs of storage and use are high. The current issues inspire intense interests in the application of nanoparticles in the field of biomedicine and water contamination. ${ }^{[1-4]}$

In 2007, Yan and coworkers $^{[5]}$ reported that magnetic nanoparticles possess an intrinsic enzyme mimetic activity similar to that found in the natural peroxidase, which are widely used to oxidize organic substrates in the treatment of wastewater or as detection tools. Since then, many peroxides-like enzymes have been synthesized, ${ }^{[5-17]}$ such as multi-walled carbon nanotube loaded $\mathrm{Fe}_{3} \mathrm{O}_{4}$ nanoparticles, ${ }^{[18]}$ gold nanoparticle functionalized with graphene quantum dots (GQD@AuNPs), etc. ${ }^{[19-30]}$ Compared with the horse radish peroxidase (HRP), these nanoparticles with high stability can be repeatedly used and have high efficiency of peroxides-like activity, and also have potential applications in degrading phenolic pollutants in waste water.

Nowadays, researchers always concentrate on one metallic oxide, and have never explored multiple nano-metallic oxides. However, there are still questions of whether those nano-metallic oxides have commonness when acting as enzymes, how they react when put in different conditions, and what are the factors that affect the peroxidase-like properties. In this paper, six types of different nano-metallic oxides were studied as peroxidase-like enzymes $\left(\mathrm{Co}_{3} \mathrm{O}_{4}, \mathrm{CrO}_{x}, \mathrm{NiO}, \mathrm{MnO}_{x}\right.$, $\mathrm{CuO}, \mathrm{Fe}_{3} \mathrm{O}_{4}$ ). 3,3',5,5'-Tetramethylbenzidine (TMB), and 2,2'-azinobis[3-ethylbenzothiazoline-6-sulfonicacid]-diammonium salt (ABTS) was used as substrates, which are typically employed as HRP substrates in various bioassays. By changing the amounts of metal-oxide nanoparticles, $\mathrm{pH}$ value, the concentration of $\mathrm{H}_{2} \mathrm{O}_{2}$, reaction time, and so on, peroxidase-like characteristics of all the six types of nano-metallic oxides were probed.

\section{Experimental}

\section{Reagents and instruments}

The commercial 3,3',5,5'-tetramethylbenzidine and 2,2'-azinobis-(3-ethylbenzthiazoline-6-sulphonate) were purchased from Sigma-Aldrich. Hydrogen peroxide $\left(\mathrm{H}_{2} \mathrm{O}_{2}\right)$, sodium acetate $(\mathrm{NaAc}), \mathrm{Na}_{2} \mathrm{CO}_{3}$ and nitrates $\left[\mathrm{Co}\left(\mathrm{NO}_{3}\right)_{2}, \mathrm{Cr}\left(\mathrm{NO}_{3}\right)_{3}, \mathrm{Ni}\left(\mathrm{NO}_{3}\right)_{2}, \mathrm{Mn}\left(\mathrm{NO}_{3}\right)_{2}, \mathrm{Cu}\left(\mathrm{NO}_{3}\right)_{2}\right.$ or $\mathrm{Fe}\left(\mathrm{NO}_{3}\right)_{2}$ ] were purchased from Sinopharm Chemical Reagent Company. All of the solvents were analytical reagent grade and were used without any pretreatment. Water used during the experiment was obtained from a Millipore water purification system (18.2 M 2 , Milli-Q, Millipore).

The absorbance value was monitored using Bio-red iMark spectrophotometer at $655 \mathrm{~nm}$. X-ray diffraction

\footnotetext{
* E-mail: pingw2006@163.com, hdn_nercn@163.com; Tel.: 0086-021-34291286-8035; Fax: 0086-021-34291125 Received February 18, 2016; accepted March 22, 2016; published online March 29, 2016.

$\dagger$ These authors contributed equally to this work.
} 
(XRD) patterns were recorded on a D/max-2600 PC (Rigaku Corporation) diffractometer equipped with a $\mathrm{Cu}$ $\mathrm{K} \alpha$ radiation source $(\lambda=0.15432 \mathrm{~nm})$, operating at 40 $\mathrm{kV}$ and $40 \mathrm{~mA}$. Brunauer-Emmett-Teller (BET) surface areas of samples were measured by nitrogen adsorption at $-196{ }^{\circ} \mathrm{C}$ using a Micromeritics ASAP 2020 apparatus. Transmission electron microscope (TEM) analyses were performed with a JEM-2100F microscope operated at $120 \mathrm{kV}$.

\section{Preparation of metal oxides}

At room temperature $\left(25{ }^{\circ} \mathrm{C}\right), 20 \mathrm{~mL}$ aqueous solution of nitrate $\left[\mathrm{Co}\left(\mathrm{NO}_{3}\right)_{2}, \quad \mathrm{Cr}\left(\mathrm{NO}_{3}\right)_{3}, \quad \mathrm{Ni}\left(\mathrm{NO}_{3}\right)_{2}\right.$, $\mathrm{Mn}\left(\mathrm{NO}_{3}\right)_{2}, \mathrm{Cu}\left(\mathrm{NO}_{3}\right)_{2}$ or $\mathrm{Fe}\left(\mathrm{NO}_{3}\right)_{2}$ ] was added drop wise to aqueous solution of $\mathrm{Na}_{2} \mathrm{CO}_{3}$ under vigorous stirring. The resulted suspension was heated to $50{ }^{\circ} \mathrm{C}$ and continuously stirred for $1 \mathrm{~h}$. The precipitates were filtered, washed repeatedly with deionized water till neutrality, dried at $100{ }^{\circ} \mathrm{C}$ and calcined at $300{ }^{\circ} \mathrm{C}$ for $3 \mathrm{~h}$. The concentration of aqueous solution of nitrate and $\mathrm{Na}_{2} \mathrm{CO}_{3}$ were both $1 \mathrm{~mol} / \mathrm{L}$, and the amount of $\mathrm{Na}_{2} \mathrm{CO}_{3}$ was that the transition metal nitrate was completely precipitated.

\section{Influence of different amounts of metal oxides on reaction}

$100 \mu \mathrm{L}$ TMB $(5 \mathrm{mg} / \mathrm{mL})$ was mixed with a series amounts of metal oxides nanoparticles in centrifuge tubes. Different amount of Milli-Q water was used to make sure the final volume was $200 \mu \mathrm{L}$. The absorbance value of the solution was measured by Bio-red iMark spectrophotometer after $30 \mathrm{~min}$.

\section{Influence of the amount of $\mathrm{H}_{2} \mathrm{O}_{2}$ and $\mathrm{pH}$ on reaction}

Aliquots $(50 \mu \mathrm{L})$ of different metal oxides nanoparticles were mixed with $20 \mu \mathrm{L}$ TMB/ABTS $(5 \mathrm{mg} / \mathrm{mL})$ with a series concentration of $\mathrm{H}_{2} \mathrm{O}_{2}$ in centrifuge tubes. Different amount of sodium acetate buffer solution was used to make sure the final volume was $200 \mu \mathrm{L}$. To assess the influence of $\mathrm{pH}$ value, we adjusted the $\mathrm{pH}$ value of the solution. Then, the absorbance value of the solution was measured by Bio-red iMark spectrophotometer at room temperature.

\section{Results and Discussion}

In order to determine the crystal phase composition and grain the size of oxide catalyst, the XRD characterization of the catalyst was carried out (Figure 1). XRD spectra show that the four oxides of $\mathrm{Fe}_{3} \mathrm{O}_{4}, \mathrm{Co}_{3} \mathrm{O}_{4}$, $\mathrm{NiO}, \mathrm{CuO}$ are pure metallic oxides; manganeses oxide are mixed of $\mathrm{Mn}_{2} \mathrm{O}_{3}$ and $\mathrm{MnO}_{2}$, chromic oxide is amorphous oxide. According to the formula of Scherrer, the size of these metallic oxides was 10, 9, 4, 23, $6 \mathrm{~nm}$ (Table 1), and the size of amorphous chromium oxide was unable to calculate. As shown in Figure 2, the size of metallic oxides was basically the same with the calculated results. Besides this, specific surface is an impor- tant factor affecting the activity of catalyst. Based on the BET physical adsorption, we obtained the specific surface of $\mathrm{Fe}_{3} \mathrm{O}_{4}, \mathrm{Co}_{3} \mathrm{O}_{4}, \mathrm{NiO}, \mathrm{CuO}, \mathrm{MnO}_{x}, \mathrm{CrO}_{x}$, respectively (Table 1).

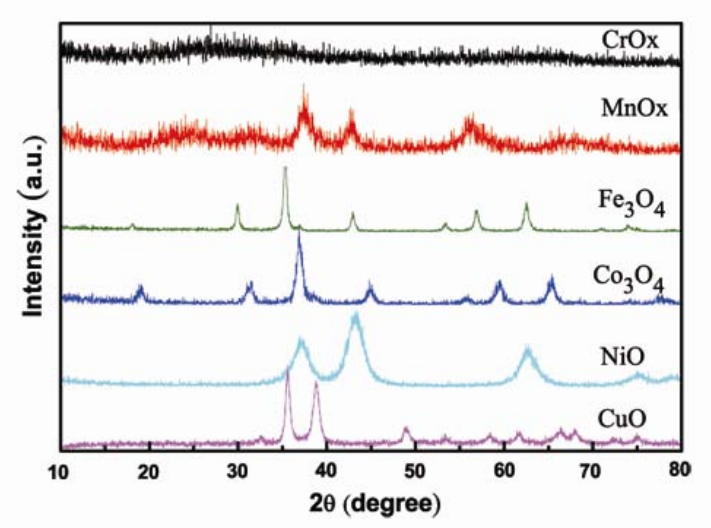

Figure 1 XRD patterns of six types of metal oxides materials.

Table 1 Comparison of the properties of six metal oxides

\begin{tabular}{cccc}
\hline Sample & $\begin{array}{c}\mathrm{SBET} / \\
\left(\mathrm{m}^{2} \cdot \mathrm{g}^{-1}\right)\end{array}$ & $\begin{array}{c}\mathrm{DNP}^{a} / \\
(\mathrm{nm})\end{array}$ & $\begin{array}{c}\text { Specific rate }^{b} / \\
\left(\mathrm{mol} \cdot \mathrm{m}^{-2} \cdot \mathrm{h}^{-1}\right)\end{array}$ \\
\hline $\mathrm{Co}_{3} \mathrm{O}_{4}$ & 100 & 9 & $3.91 \times 10^{-4}$ \\
$\mathrm{CrO}_{x}$ & 40 & - & $1.20 \times 10^{-3}$ \\
$\mathrm{NiO}$ & 195 & 4 & $1.98 \times 10^{-5}$ \\
$\mathrm{MnO}_{x}$ & 156 & 6 & $2.84 \times 10^{-4}$ \\
$\mathrm{CuO}$ & 39 & 23 & $9.17 \times 10^{-5}$ \\
$\mathrm{Fe}_{3} \mathrm{O}_{4}$ & 89 & 10 & $3.22 \times 10^{-5}$ \\
\hline
\end{tabular}

${ }^{a}$ Measured by XRD; ${ }^{b}$ Tested at $40 \mathrm{~min}$.

The characteristics of the peroxidase-like enzymes of the six different metallic oxides were compared with each other. As shown in Figure 3, after $30 \mathrm{~min}$, the catalytic activity of $\mathrm{Co}_{3} \mathrm{O}_{4}, \mathrm{CrO}, \mathrm{MnO}_{x}$ is significantly better than the other three metallic oxides. In general, the catalytic activity was enhanced with the increase of the amounts of metal oxides. The catalytic activity of $\mathrm{Co}_{3} \mathrm{O}_{4}, \mathrm{CrO}, \mathrm{MnO}_{x}$ reaches the highest value when the amounts is near $0.1 \mathrm{mg} / \mathrm{mL}$. The solution has turned from blue to yellow when the amounts continue to increase, which is mainly due to excessive reaction.

In order to test the intrinsic activity of the catalysts, we obtained the specific activity per unit area of the catalyst according to the specific surface of metallic oxide (Table 1, Figure 3b). It shows that $\mathrm{CrO}_{x}$ has the highest specific activity, while $\mathrm{Co}_{3} \mathrm{O}_{4}$ and $\mathrm{MnO}_{x}$ have no obvious advantage despite their higher activity. That demonstrates that $\mathrm{CrO}_{x}$ has better catalytic activity than the other oxides. However, the catalytic efficiency of the metal oxide is generally lower than that of HRP (Figure $3 c$ ), whereas the metal oxide holds the advantages of low cost, simple synthesis, easy to store, and reusability, therefore, it is highly applicable in many aspects. 

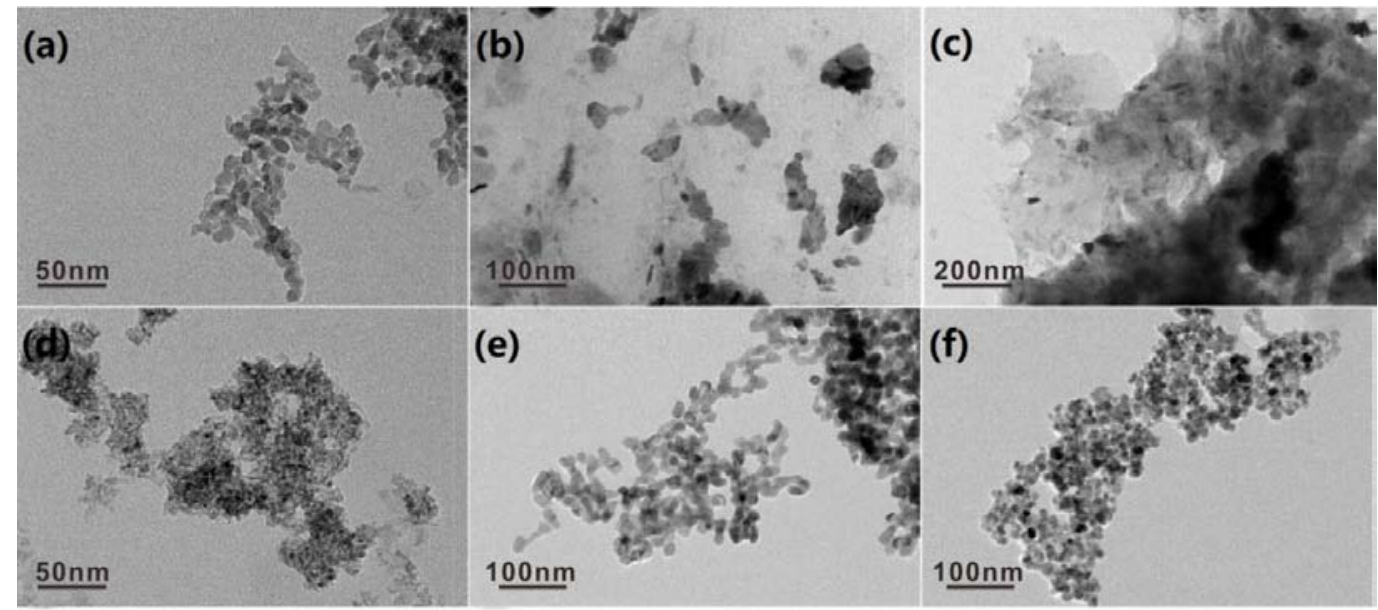

(f)
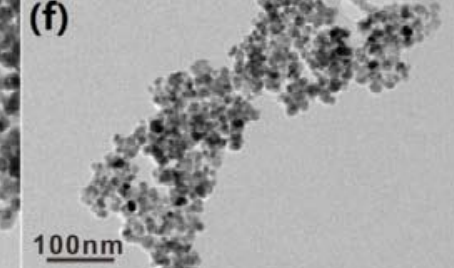

Figure 2 TEM images of (a) $\mathrm{Co}_{3} \mathrm{O}_{4}$, (b) $\mathrm{CrO}_{x}$, (c) $\mathrm{MnO}_{x}$, (d) $\mathrm{NiO}$, (e) $\mathrm{CuO}$, and (f) $\mathrm{Fe}_{3} \mathrm{O}_{4}$.
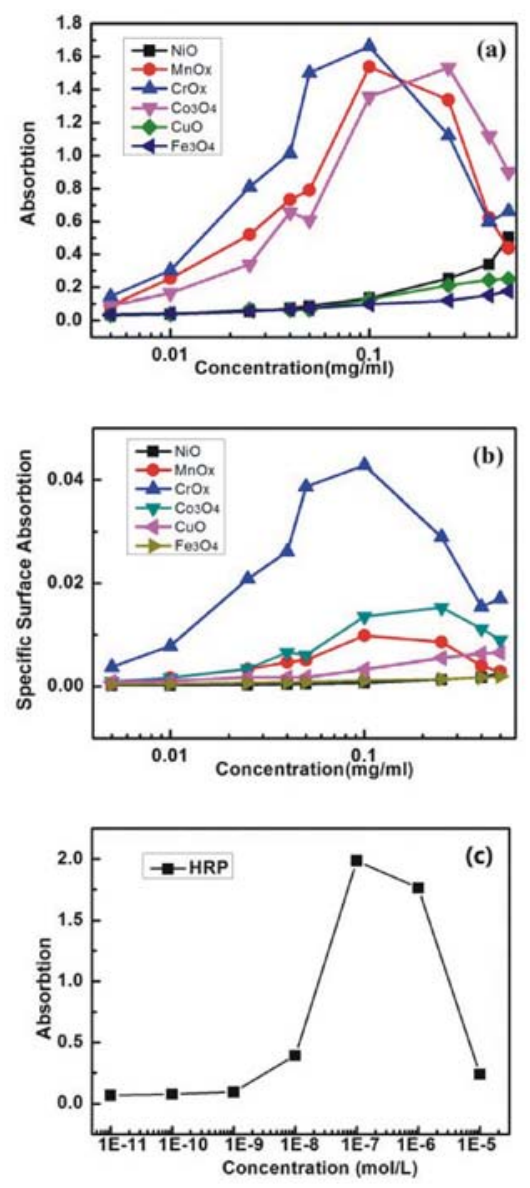

Figure 3 The peroxidase-like activity of the metal oxides is related to the amounts of the metal oxides. (a) Plot of metal oxides amounts versus the absorbance; (b) Plot of metal oxides amounts versus the absorbance in the specific surface area; (c) Plot of HRP concentration versus the absorbance.

The absorption value of most catalyzed system increases along with the increase of $\mathrm{H}_{2} \mathrm{O}_{2}$ concentration except $\mathrm{CrO}_{x}$ (Figure 4). We suspect that this is because the catalytic activity of $\mathrm{CrO}_{x}$ is too strong to be affected by the $\mathrm{H}_{2} \mathrm{O}_{2}$ concentration. For $\mathrm{MnO}_{x}$, the catalytic performance is higher with lower $\mathrm{H}_{2} \mathrm{O}_{2}$ concentration. This is because the addition of $\mathrm{H}_{2} \mathrm{O}_{2}$ makes the reaction too intense, and thus the color reaction changed from blue to colorless. To prove that, we studied the reaction law of these six kinds of metal oxides with time (Figure 5). The absorbtion values of $\mathrm{Co}_{3} \mathrm{O}_{4}, \mathrm{CrO}_{x}$ and $\mathrm{MnO}_{x}$ decreased rapidly within $40-100 \mathrm{~min}$, and those of $\mathrm{Fe}_{3} \mathrm{O}_{4}$, $\mathrm{CuO}$ and $\mathrm{NiO}$ changed little during the test time (Figure 6). Actually, the reaction solutions of $\mathrm{Co}_{3} \mathrm{O}_{4}, \mathrm{CrO}_{x}$ and $\mathrm{MnO}_{x}$ changed from blue to colorless when the reaction time was long enough $(>4 \mathrm{~d})$. Moreover, the reaction systems of $\mathrm{Fe}_{3} \mathrm{O}_{4}, \mathrm{CuO}$ and $\mathrm{NiO}$ also changed from blue to colorless after more than $10 \mathrm{~d}$.

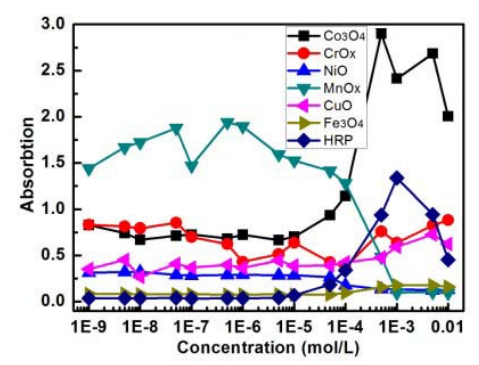

Figure 4 Effects of $\mathrm{H}_{2} \mathrm{O}_{2}$ concentration on the catalytic reaction of TMB.

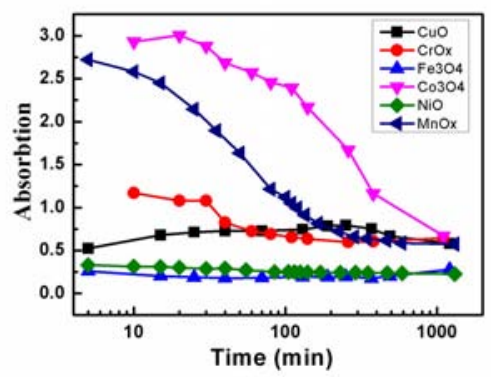

Figure 5 Effects of time on the catalytic reaction. 


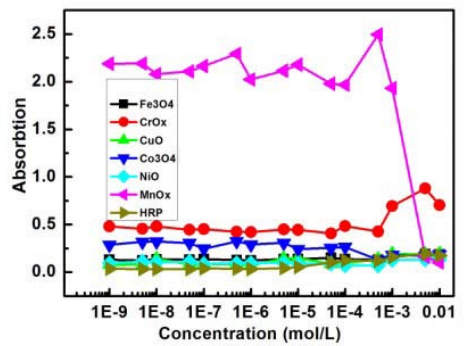

Figure 6 Effects of $\mathrm{H}_{2} \mathrm{O}_{2}$ concentration on the catalytic reaction of ABTS.

In addition to the TMB, we also verified the catalytic effect of the ABTS as the substrate. The catalytic ability of $\mathrm{MnO}_{x}$ is much higher than that of the other kinds of nanoparticles. Similarly, the absorbtion decreases as the $\mathrm{H}_{2} \mathrm{O}_{2}$ concentration increases for the same reason. The absorbtion value of $\mathrm{CuO}$ and $\mathrm{Fe}_{3} \mathrm{O}_{4}$ still increase along with the increase of $\mathrm{H}_{2} \mathrm{O}_{2}$ concentration, whereas the catalytic property of $\mathrm{NiO}, \mathrm{CrO}_{x}$ and $\mathrm{Co}_{3} \mathrm{O}_{4}$ is different from that of TMB as the substrate. To explore the reason for the above, the influence of $\mathrm{pH}$ value was studied (Figure 7). Under the acid conditions, the metal oxides show catalytic properties, and the absorbtion increases along with the decrease of $\mathrm{pH}$ value. In addition, $\mathrm{NiO}$ has the most suitable $\mathrm{pH}$ value in $\mathrm{pH} 5$. This may introduce the difference of the catalytic properties of the peroxidase-like enzymes between TMB and ABTS.

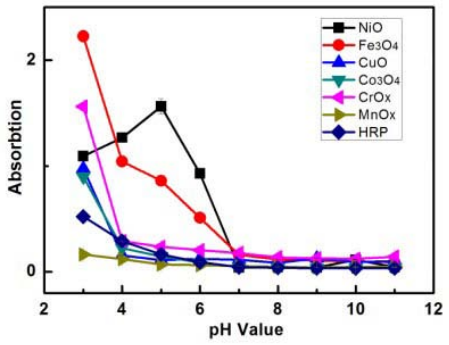

Figure 7 Effects of $\mathrm{pH}$ on the catalytic reaction of ABTS.

In the experiment, we found that $\mathrm{Co}_{3} \mathrm{O}_{4}, \mathrm{CrO}_{x}, \mathrm{MnO}_{x}$, $\mathrm{NiO}$ could still effectively catalyze TMB and ABTS in the absence of $\mathrm{H}_{2} \mathrm{O}_{2}$. As shown in Figure 8, these four metal oxides have oxidize-like enzyme properties and this phenomenon is worth to be studied in detail as the next subject.

\section{Conclusions}

In this paper, the peroxidase-like properties of six types of nano metal oxides $\left(\mathrm{Co}_{3} \mathrm{O}_{4}, \mathrm{CrO}_{x}, \mathrm{NiO}, \mathrm{MnO}_{x}\right.$, $\mathrm{CuO}, \mathrm{Fe}_{3} \mathrm{O}_{4}$ ) were studied. The effects of TMB, ABTS, amounts, time, $\mathrm{pH}$, etc. on the catalytic reaction were probed. At the same time, we found that $\mathrm{Co}_{3} \mathrm{O}_{4}, \mathrm{CrO}_{x}$, $\mathrm{NiO}, \mathrm{MnO}_{x}$ have the oxidase-like properties. This re-

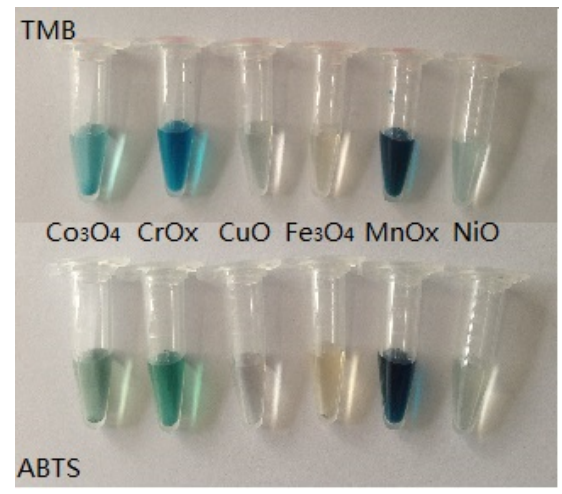

Figure 8 Color changes after the catalytic reaction in the absence of $\mathrm{H}_{2} \mathrm{O}_{2}$.

search has potential applications in biomedical detection and the degradation of the phenolic pollutants in waste water.

\section{Acknowledgement}

This work is supported by the National Key Research Program of China (No. 2013CB933200)

\section{References}

[1] Qian, H.; Pretzer, L. A.; Velazquez, J. C.; Zhao, Z.; Wong, M. S. J. Chem. Technol. Biol. 2013, 88, 735.

[2] Barakat, M. A.; Al-Hutailah, R. I.; Qayyum, E.; Rashid, J.; Kuhn, J. N. Environ. Technol. 2014, 35, 137.

[3] Nashaat, N. N. In Applications of Nanomaterials for Water Quality, Future Science Ltd, London, 2013, p. 52.

[4] Wang, W.; Mao, Q.; He, H.; Zhou, M. Water Sci. Technol. 2013, 68, 2367.

[5] Gao, L.; Zhuang, J.; Nie, L.; Zhang J.; Zhang, Y.; Gu, N.; Wang, T.; Feng, J.; Yang, D.; Perrett, S.; Yan, X. Nat. Nano 2007, 2, 577.

[6] Liu, X.; Wang, Q.; Zhao, H.; Zhang, L.; Su, Y.; Lv, Y. Analyst 2012, $137,4552$.

[7] Zheng, X.; Liu, Q.; Jing, C.; Li, Y.; Li, D.; Luo, W.; Wen, Y.; He, Y.; Huang, Q.; Long, Y.-T.; Fan, C. Angew. Chem., Int. Ed. 2011, 50, 11994.

[8] Luo, W.; Zhu, C.; Su, S.; Li, D.; He, Y.; Huang, Q.; Fan, C. ACS Nano 2010, 4, 7451.

[9] He, W.; Liu, Y.; Yuan, J.; Yin, J.-J.; Wu, X.; Hu, X.; Zhang, K.; Liu, J.; Chen, C.; Ji, Y.; Guo, Y. Biomaterials 2011, 32, 1139.

[10] He, W.; Wu, X.; Liu, J.; Hu, X.; Zhang, K.; Hou, S.; Zhou, W.; Xie, S. Chem. Mater. 2010, 22, 2988.

[11] Shi, W.; Zhang, X.; He, S.; Huang, Y. Chem. Commun. 2011, 47, 10785.

[12] Fan, J.; Yin, J.-J.; Ning, B.; Wu, X.; Hu, Y.; Ferrari, M.; Anderson, G. J.; Wei, J.; Zhao, Y.; Nie, G. Biomaterials 2011, 32, 1611.

[13] Wei, H.; Wang, E. Anal. Chem. 2008, 80, 2250.

[14] Chen, H.; Li, Y.; Zhang, F.; Zhang, G.; Fan, X. J. Mater. Chem. 2011, 21, 17658.

[15] Guo, Y.; Deng, L.; Li, J.; Guo, S.; Wang, E.; Dong, S. ACS Nano 2011, 5, 1282.

[16] Mu, J.; Wang, Y.; Zhao, M.; Zhang L. Chem. Commun. 2012, 48, 2540.

[17] Wang, S.; Chen, W.; Liu, A.-L.; Hong, L.; Deng, H.-H.; Lin, X.-H. ChemPhysChem 2012, 13, 1199.

[18] Zuo, X.; Peng, C.; Huang, Q.; Song, S.; Wang, L.; Li, D.; Fan, C. Nano Res. 2009, 2, 617.

[19] Zheng, T.; Zhang, Q.; Feng, S.; Zhu, J.-J.; Wang, Q.; Wang, H. J. Am. 
Chem. Soc. 2014, 136, 2288

[20] Song, Y.; Wang, X.; Zhao, C.; Qu, K.; Ren, J.; Qu, X. Chem. Eur. J. 2010, 16, 3617.

[21] Wang, X.; Qu, K.; Xu, B.; Ren, J.; Qu, X. Nano Res. 2011, 4, 908.

[22] Gao, H.; Xiao, F.; Ching, C. B.; Duan, H. ACS Appl. Mater. Interfaces 2011, 3, 3049.

[23] Chen, W.; Chen, J.; Liu, A.-L.; Wang, L.-M.; Li, G.-W.; Lin, X.-H. ChemCatChem 2011, 3, 1151.

[24] Chen, W.; Chen, J.; Feng, Y.-B.; Hong, L.; Chen, Q.-Y.; Wu, L.-F.; Lin, X.-H.; Xia, X.-H. Analyst 2012, 137, 1706.

[25] Maji, S. K.; Dutta, A. K.; Srivastava, D. N.; Paul, P.; Mondal, A.;
Adhikary, B. J. Mol. Catal. A: Chem. 2012, 358, 1.

[26] Ma, M.; Zhang, Y.; Gu, N. Colloid Surf. A: Physicochem. Eng. Asp. 2011, 373, 6 .

[27] Jv, Y.; Li, B.; Cao, R. Chem. Commun. 2010, 46, 8017.

[28] Zhang, X.-Q.; Gong, S.-W.; Zhang, Y.; Yang, T.; Wang, C.-Y.; Gu, N. J. Mater. Chem. 2010, 20, 5110.

[29] Wang, N.; Zhu, L.; Wang, D.; Wang, M.; Lin, Z.; Tang, H. Ultrason. Sonochem. 2010, 17, 526.

[30] Asati, A.; Santra, S.; Kaittanis, C.; Nath, S.; Perez, J. M. Angew. Chem., Int. Ed. 2009, 48, 2308. 